\title{
Clinical Study Citation
}

National Cancer Institute

\section{Source}

National Cancer Institute. Clinical Study Citation. NCI Thesaurus. Code C127788.

A bibliographical reference to a particular study. 